\title{
Orogeny forced terrestrial climate variation during the late Eocene- early Oligocene in Europe
}

\author{
László Kocsis ${ }^{1}$, Péter Ozsvárt ${ }^{2}$, Damien Becker ${ }^{3,5}$, Reinhard Ziegler ${ }^{4}$, Laureline Scherler ${ }^{5}$, and Vlad Codrea \\ 'Institute of Earth Sciences, University of Lausanne, UNIL-Geopolis, 1015 Lausanne, Switzerland \\ 2MTA-MTM-ELTE Research Group for Paleontology, PO Box-137, 1431 Budapest, Hungary \\ 3Jurassica Muséum, Route de Fontenais 21, 2900 Porrentruy, Switzerland \\ ${ }^{4}$ Staatliches Museum für Naturkunde Stuttgart, Rosenstein 1, 70191 Stuttgart, Germany \\ ${ }_{5}^{5}$ Paléontologie A16, Office de la Culture, République et Canton du Jura, Hôtel des Halles, 2900 Porrentruy, Switzerland \\ ${ }^{6}$ Faculty of Biology and Geology, Babes-Bolyai University, 1, Kogalniceanu Strasse 400084 Cluj-Napoca, Romania
}

\section{ABSTRACT}

Terrestrial climatic data reflect variable and often conflicting responses to the global cooling event at the Eocene-Oligocene transition (ca. $34 \mathrm{Ma}$ ). Stable isotopic compositions of the tooth enamel of large, water-dependent, herbivorous terrestrial mammals are investigated here to better understand the European continental climate during the late Eoceneearly Oligocene. High $\delta^{18} \mathrm{O}_{\mathrm{PO}_{4}}$ and $\delta^{13} \mathrm{C}$ values reflect a semiarid climate and ecosystem in the late Eocene. In the west-southwest region of Europe, these conditions prevailed until at least $33 \mathrm{Ma}$, after which it became more humid. A similar change was recorded north of the Alpine thrust, but it occurred 2 m.y. earlier. The north and west-southwest regions show a significant offset in $\delta^{18} \mathrm{O}_{\mathrm{PO}_{4}}$ composition between 35 and $31 \mathrm{Ma}$, indicating the influence of different air trajectories with different moisture sources (Atlantic versus Tethys). This also marks the presence of an orographic height in central Europe from the latest Eocene. After $31 \mathrm{Ma}$, a large drop in $\delta^{18} \mathrm{O}_{\mathrm{PO}_{4}}$ is registered, explained by altitude-induced fractionation on meteoric water isotopic composition. The related paleoaltitude change is estimated to be $1200 \mathrm{~m}$, and the uplift could have taken place along the Alpine-Dinaridic orogenic system.

\section{INTRODUCTION}

The early Cenozoic climate has been intensively studied, and compilations of paleoclimatic data have revealed that Earth's climate changed dramatically during this era (Zachos et al., 2001). In the Paleogene, the warm greenhouse world gradually changed to icehouse conditions, with permanent ice sheets on Antarctica. The major shift between the two climate modes is placed at the Eocene-Oligocene transition (EOT, $34 \mathrm{Ma}$ ), when rapid step-wise shifts toward higher $\delta^{18} \mathrm{O}$ values occurred in the marine oxygen isotopic record (Katz et al., 2008). The terrestrial responses to this climatic change show strong spatial heterogeneity, and the implications of the reported paleoclimatic records are often debated (e.g.,
Grimes et al., 2005; Zanazzi et al., 2007; Hren et al., 2013). We investigated the stable isotopic compositions of tooth enamel of large grounddwelling herbivorous mammals from Eocene and Oligocene localities. A major Eocene-Oligocene faunal turnover that corresponds to the extinction and origination event called the "Grande Coupure" is recorded in Europe (Stehlin, 1909). Many endemic European Eocene mammals became extinct (e.g., Lophiodontidae) and gave way to new Asian immigrant groups (e.g., Rhinocerotidae) (Hooker et al., 2004).

Mammalian tooth enamel is composed of bioapatite $\left[\mathrm{Ca}_{5}\left(\mathrm{PO}_{4}, \mathrm{CO}_{3}\right)_{3}\left(\mathrm{CO}_{3}, \mathrm{OH}\right)\right]$ with greater crystal size and lower organic and carbonate contents than bone or dentine. These characteristics render enamel the most resistant bioapatite archive to late diagenetic and bacterial alteration. It is therefore the most suitable material to obtain an in vivo isotopic signal (e.g., Kohn and Cerling, 2002). The oxygen isotopic composition of teeth and bones of water-dependent herbivorous animals strongly depends on the isotopic composition of drinking water (e.g., local meteoric water: $\delta^{18} \mathrm{O}_{\mathrm{MW}}$ and/or other water sources) (Luz et al., 1984; Kohn and Cerling, 2002) and correlates weakly with relative humidity (e.g., Kohn, 1996). The $\delta^{18} \mathrm{O}_{\mathrm{Mw}}$ reflects the isotopic composition of the moisture source and alteration during transport (e.g., latitude, altitude, continental effect, amount of precipitation), but it also shows significant correlation with mean annual temperature (MAT) at middle and high latitudes (e.g., Fricke and O'Neil, 1999). The carbon isotopic composition of the teeth reflects the diet of the animals (Kohn and Cerling, 2002) and in herbivores indirectly reflects the composition of the paleoflora. In the Eocene-Oligocene, the paleoflora was dominated by $\mathrm{C}_{3}$ plants, as the $\mathrm{C}_{4}$ photosynthetic carbon fixation was not yet widespread (e.g., Kohn, 2010). Therefore, any variation in the $\delta^{13} \mathrm{C}$ of $\mathrm{C}_{3}$ plants can be linked to environmental changes (e.g., water stress, aridity, canopy effect; Farquhar et al., 1989).

\section{METHODS AND RESULTS}

We studied fossils from 24 localities across Europe's middle latitudes $\left(40^{\circ}-50^{\circ} \mathrm{N}\right.$; Fig. 1)

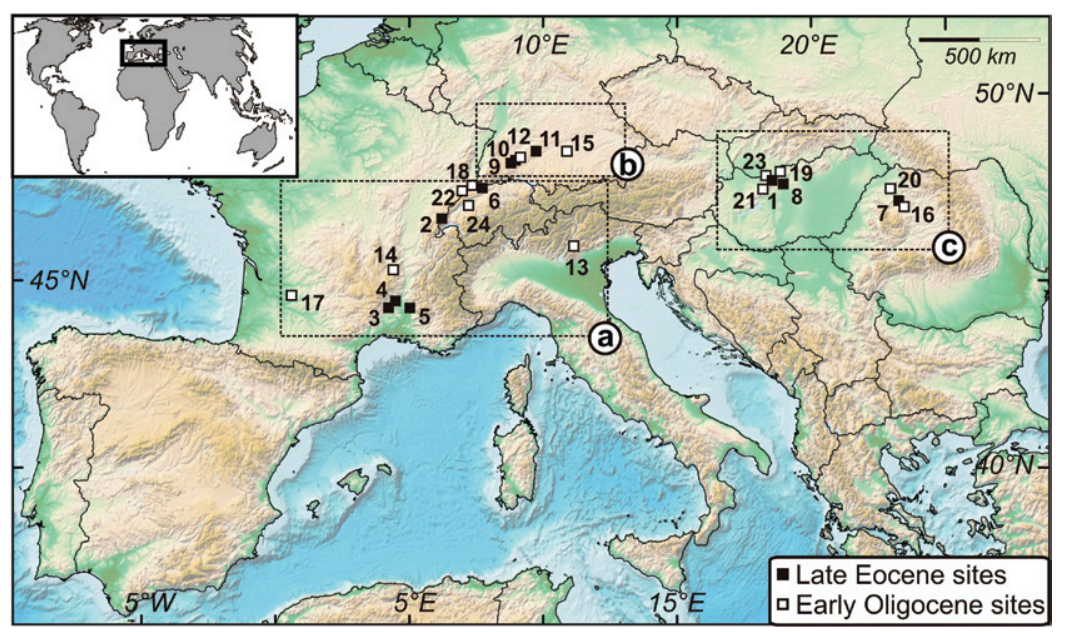

Figure 1. Study fossil sites in Europe. 1-Csordakút; 2Mormont: Eclépens-A and Station (Mammal Paleogene Reference Level MP16) and Eclépens-C and Entreroche (MP19); 3-St. Mamert du Gard; 4-Euzet-les-Bains; 5-La Débruge; 6-Gösgen-Canal; 7-Radaia; 8-Budapest-MTM; 9-Liptingen 5 and 13A; 10-Neuhausen; 11-Mähringen; 12-Frohnstetten; 13-Monteviale; 14Ronzon; 15-Möhren-13 (MP21) and Möhren-19 (MP22); 16-Cluj (MP22 and MP23-24); 17-Villebramar; 18Kleinblauen; 19-Budapest-A (MP23+) and Budapest-B (MP23-24); 20-Aghires; 21-Csákberény; 22-Poillat; 23-Tatabánya; 24-Bumbach. Details in Tables DR1 and DR2 (see footnote 1). The map is derived from the National Oceanic and Atmospheric Administration (NOAA) database (http://www.noaa.gov/). Rectangles indicate regions referred in the text as (a) west-southwest, (b) north, and (c) east-southeast. Note that among the eastern sites, some had a rather southern position during the late Eocene (cf. Fig. 3). 
covering a biostratigraphic range from MP15 to MP25 (European Mammal Paleogene Reference Levels). These levels are used for our age model according to the geological time scale of Gradstein et al. (2012). Sites with well-constrained MP ages and available fauna were sampled, together with localities recording sporadic occurrences of mammals, in order to expand our data set in both time and space (Fig. 2; see the GSA Data Repository ${ }^{1}$ and Table DR1 therein). Tooth enamel was sampled along the vertical axis to average any possible seasonal variation that can be recorded in a single tooth. To trace possible taxonomical disparity, several species were chosen from Perissodactyla and Artiodactyla families (e.g., Palaeotheriidae, Lophiodontidae, Rhinocerotidae, and Anthracotheriidae, and Anoplotheriidae; see Table DR2; Fig. 2).

From the different oxygen-bearing ions in bioapatite, the phosphate group $\left[\mathrm{PO}_{4}^{3-} \rightarrow\right.$ $\delta^{18} \mathrm{O}_{\mathrm{PO}_{4}}$ ] is the most resistant to diagenetic alteration (e.g., Zazzo et al., 2004), and so it was separated and analyzed. Of the samples, $\sim 75 \%$ were also analyzed for the carbon and oxygen isotopic compositions of the structural carbon- ate $\left[\mathrm{CO}_{3}{ }^{2-} \rightarrow \delta^{13} \mathrm{C}\right.$ and $\left.\delta^{18} \mathrm{O}_{\mathrm{CO}_{3}}\right]$. Sampling techniques, processing protocols of the teeth, and data are reported in the Data Repository, and the $\delta^{18} \mathrm{O}_{\mathrm{PO}_{4}}$ and $\delta^{13} \mathrm{C}$ values are plotted in Figure 2. The strong correlation between the two oxygen isotopic compositions $\left(\mathrm{CO}_{3}{ }^{2-}\right.$ versus $\mathrm{PO}_{4}^{3-} ; \mathrm{R}^{2}=$ $0.78 ; \mathrm{p}<0.05$ ) supports good preservation of the tooth enamel with no considerable alteration of their isotopic compositions (see Fig. DR1).

\section{Testing Physiological and Habitat Effects}

The physiological controls on oxygen isotopic fractionation for different mammal species are well documented (e.g., Kohn, 1996), but cannot be accurately constrained for fossil groups; this is especially difficult considering the faunal turnover in the European continental vertebrates near the EOT. Because there can be huge differences in water dependencies within the modern members of the perissodactyls and artiodactyls, statistical tests were performed on key localities where several samples were available (Monteviale, Italy; Möhren 13 and 19, Germany; Villebramar, France; see Fig. 1). These tests indicate that taxonomic differences have little role in the isotope variances, and there is no obvious pattern between the two orders (Table DR3; Fig. 2C). In contrast, few subgroups (from species to families) yielded significant offsets; however, it is difficult to resolve whether these truly reflect different water dependencies or are simply due to mixed fauna assemblages (i.e., seasonal migration). However, if the average isotopic compositions are taken for all the localities, a clear geographical variation appears (Fig. 2D). The interpretation here is that the environmental factors had more important effects on the overall $\delta^{18} \mathrm{O}_{\mathrm{PO}_{4}}$ values than did physiological fractionation. In addition, the $\delta^{13} \mathrm{C}$ data do not show any significantly different food preference between the groups (see Table DR3), with exception of the site La Débruge (France), where only two teeth were analyzed (Figs. 2A and $2 \mathrm{~B}$ ).

\section{DISCUSSION AND INTERPRETATIONS}

\section{Carbon Isotopic Composition}

The site-average $\delta^{13} \mathrm{C}$ data reflect geographical variation (Fig. 2B); generally (1) the
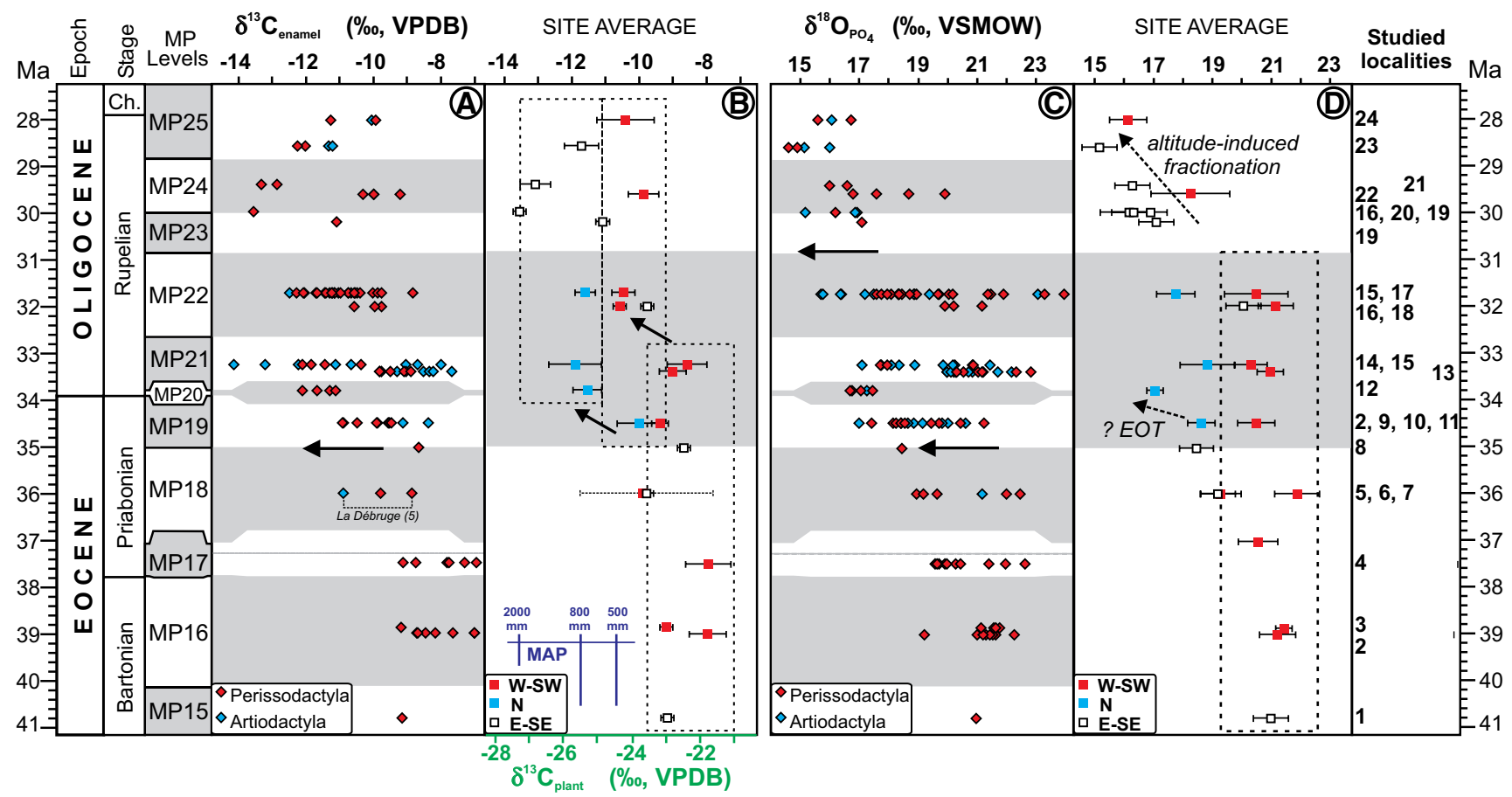

Figure 2. Carbon isotopic composition $\left[\delta^{13} \mathrm{C}\right]$ and oxygen isotopic composition of the phosphate component [ $\delta^{18} \mathrm{O}_{\mathrm{PO}}$ ] of herbivore tooth enamel. All individual samples are plotted separately for Perissodactyla and Artiodactyla in $A$ and $C$, while the site average values appear in $B$ and $D . \delta^{13} C$ values of the enamel are converted to ancient plant $\delta^{13} C$ composition in $B$ (see Kohn and Cerling, 2002) and used for estimating mean annual precipitation (MAP; see text, and Kohn 2010). Within an MP level, the sites are further separated relative to their age whenever possible. Sporadic fossils that belong to more than one MP level (European Mammal Paleogene Reference) are plotted at the level boundaries. The northern localities in the MP19 level (fossil sites of 9-11; see Fig. 1) are averaged jointly as they are statistically indistinguishable (t-test, $p<0.05)$. Error bars represent $1.96 \times \mathrm{SE}$. Note that larger errors occur at those localities where only one sample was analyzed or when the few analyses are very different (i.e., $\delta^{13} \mathrm{C}$ at La Débruge [France]). For details, see Table DR2 (see footnote 1). Dashed rectangles signify regions that yielded similar isotopic values. Arrows correspond to major isotopic shifts or mark important isotope offsets.

${ }^{1}$ GSA Data Repository item 2014270, Table DR1 (fossil locality information), Table DR2 (analyzed samples and their isotopic compositions), Table DR3 (statistical comparison of different taxa from the four most representative localities), method of preparation of the samples for stable isotope analyses, Figure DR1 (phosphate and carbonate oxygen isotopic compositions in biogenic apatite), Figure DR2 (detailed paleogeographic maps), and references, is available online at www.geosociety.org /pubs/ft2014.htm, or on request from editing@ geosociety.org or Documents Secretary, GSA, P.O. Box 9140, Boulder, CO 80301, USA. 
west-southwest sites tend to have higher $\delta^{13} \mathrm{C}$ values, (2) the northern and the young eastern (younger than $31 \mathrm{Ma}$ ) localities have much lower $\delta^{13} \mathrm{C}$, and (3) both the north and westsouthwest regions recorded significant isotope shifts at different times. The first isotope shift appeared between MP19 and MP20 levels north of the Alpine thrust $(-1.5 \%$, Student's t-test $\left.\left[\mathrm{t}_{(9)}\right]=3.22 ; \mathrm{p}=0.01\right)$, while a similar change occurred in the west-southwest $\sim 2$ m.y. later $\left(\mathrm{MP} 21-\mathrm{MP} 22,-1.6 \% \mathrm{t}_{(28)}=6.50 ; \mathrm{p}=4.8 \times\right.$ $\left.10^{-7}\right)$. The east-southeast and west-southwest data run similarly until ca. $31 \mathrm{Ma}$, and then the eastern sites show lower $\delta^{13} \mathrm{C}$ values.

The enamel $\delta^{13} \mathrm{C}$ can be used to determine plant-food carbon isotopic composition using a fractionation factor of 1.0141 between the enamel and diet (Kohn and Cerling, 2002; Fig. 2D); this yields a range of $\delta^{13} \mathrm{C}_{\text {plant }}$ from $-20.8 \%$ o to $-27.8 \%$. Taking into account an average of $2.5 \%$ o higher atmospheric $\delta^{13} \mathrm{C}$ for the EoceneOligocene than today (Tipple et al., 2010), the obtained values correspond to the middle-high range of the overall modern $\mathrm{C}_{3}$ flora (from $-20 \%$ o to $-37 \%$; Kohn, 2010). Based on the relation between mean annual precipitation (MAP) and the $\delta^{13} \mathrm{C}$ values of $\mathrm{C}_{3}$ plants (Kohn, 2010), the high isotopic values in our late Eocene-earliest Oligocene record indicate a dry ecosystem $(<500 \mathrm{~mm}$ MAP). The decreasing $\delta^{13} \mathrm{C}$ values suggest that the climate became more humid in the north at the EOT ( $\triangle \mathrm{MAP} \sim 480 \mathrm{~mm}$, calculated at $300 \mathrm{~m}$ and $\left.50^{\circ} \mathrm{N}\right)$, while the west-southwest received more precipitation by $32 \mathrm{Ma}(\triangle \mathrm{MAP} \sim 330 \mathrm{~mm}$, calculated at $300 \mathrm{~m}$ and $45^{\circ} \mathrm{N}$ ). This suggests that moisture-rich air masses gradually extended to more southern regions (Fig. 3). After $31 \mathrm{Ma}$, the eastern region became even more humid, with MAP as much as $2000 \mathrm{~mm}$, which agrees with paleoflora studies (Mosbrugger et al., 2005; Erdei et al., 2012).

\section{Oxygen Isotopic Composition [ $\left.\delta^{18} \mathrm{O}_{\mathrm{PO}_{4}}\right]$}

The overall negative trend in this record (Fig. 2C) generally indicates that the drinking-water isotopic composition (e.g., $\delta^{18} \mathrm{O}_{\mathrm{MW}}$ ) decreased and/or relative humidity may have increased with time in the region (e.g., Kohn, 1996). The lower $\delta^{18} \mathrm{O}_{\mathrm{MW}}$ can reflect cooler temperatures (Fricke and O'Neil, 1999), but also can reflect changes in the isotopic composition of moisture sources (e.g., alteration in air-mass trajectories, and continental and/or altitude effects). The average $\delta^{18} \mathrm{O}_{\mathrm{PO}_{4}}$ values of the localities demonstrate geographic heterogeneities that indicate complex interaction among these possible causes for the observed trend (Fig. 2D). (1) The relatively southern, maritime localities show very similar, high $\delta^{18} \mathrm{O}_{\mathrm{PO}_{4}}$ values until ca. 31 Ma. (2) Localities north of the Alpine thrust, between 35 and $31 \mathrm{Ma}$, have significantly lower isotopic values $\left(\Delta \delta^{18} \mathrm{O}_{\mathrm{PO}_{4}}\right.$ of $-2.4 \%$, $\mathrm{t}_{(81)}=8.33 ; \mathrm{p}=1.7 \times 10^{-12}$ ). (3) From $31 \mathrm{Ma}$,
$1 \%$ - $1.5 \%$ isotopic offset is apparent between the west-southwest and eastern areas.

The west-southwest and southeastern localities were probably dominated by warm Tethyan moisture sources (i.e., high $\delta^{18} \mathrm{O}_{\mathrm{MW}}$ ) and/or evaporative conditions until at least $33 \mathrm{Ma}$. This concurs with the time-equivalent high $\delta^{13} \mathrm{C}$ values. In contrast, the north received more precipitation (i.e., low $\delta^{13} \mathrm{C}$ ) with low $\delta^{18} \mathrm{O}_{\mathrm{MW}}$, mostly from the North Atlantic.

The significant division in the data between the north and west-southwest regions between 35 and $31 \mathrm{Ma}$ points to the existence of a potential orographic barrier for these air masses; otherwise, more mixed isotopic values would be expected. From the late Eocene, the collision between Europe and Africa triggered the emergence of the Alpine-Dinaridic system (Schmid et al., 2008), causing isostatic readjustments that formed a mainland barrier. Therefore, certain parts could already have reached elevations that had acted as an obstacle for atmospheric circulation.

After $31 \mathrm{Ma}$, the $\delta^{18} \mathrm{O}_{\mathrm{PO}_{4}}$ values of both the west-southwest and eastern sites (Fig. 3) record a negative shift of $4.3 \%$ relative to the corresponding older sites, and $2.2 \%$ compared to the northern ones. It is important that other oxygen isotope data (reported from southern German rodent teeth), also reveal a large negative $\delta^{18} \mathrm{O}_{\mathrm{PO}_{4}}$ shift $(\sim 2.2 \%$ ) at 31-30 Ma (Héran et al., 2010; see Fig. 3). This shift further supports the sudden, wider presence of light $\delta^{18} \mathrm{O}_{\mathrm{MW}}$ in the region, even if the physiology of small mammals is quite different from the large herbivores. The isotope offset between the west-southwest and eastern regions (Fig. 2D) suggests fractionation in $\delta^{18} \mathrm{O}_{\mathrm{MW}}$ due to longer moisture transport from the Atlantic across the continent (i.e., a continental effect). This may also exclude long-term dominance of possible eastern air trajectories with moisture having low isotopic composition; otherwise, the direction of the west-east isotopic offset should be reversed. Therefore, the major air trajectories are assumed to be Westerlies from the Atlantic. However, in the eastern region, a large surface area was covered by an epicontinental sea (i.e., Central Paratethys; Fig. 3). Evaporation from this water body could have added moisture to the western air trajectories, increasing precipitation inland (i.e., low $\delta^{13} \mathrm{C}$ in the east; see Fig. 2B). Nevertheless, changes in any of these moisture sources could not have resulted in such a widespread negative isotope shift, especially when the global seawater $\delta^{18} \mathrm{O}$ composition increased during the EOT and was rather stable in the early Oligocene (e.g., Katz et al., 2008).

An increase in relative humidity can also be a factor for the negative $\delta^{18} \mathrm{O}_{\mathrm{PO}_{4}}$ shift (Kohn, 1996), but the sensitivity of water-dependent animals to relative humidity is also very low, plus the paleoflora already indicates an overall high humidity (75\%-80\%; Erdei et al., 2012) with no

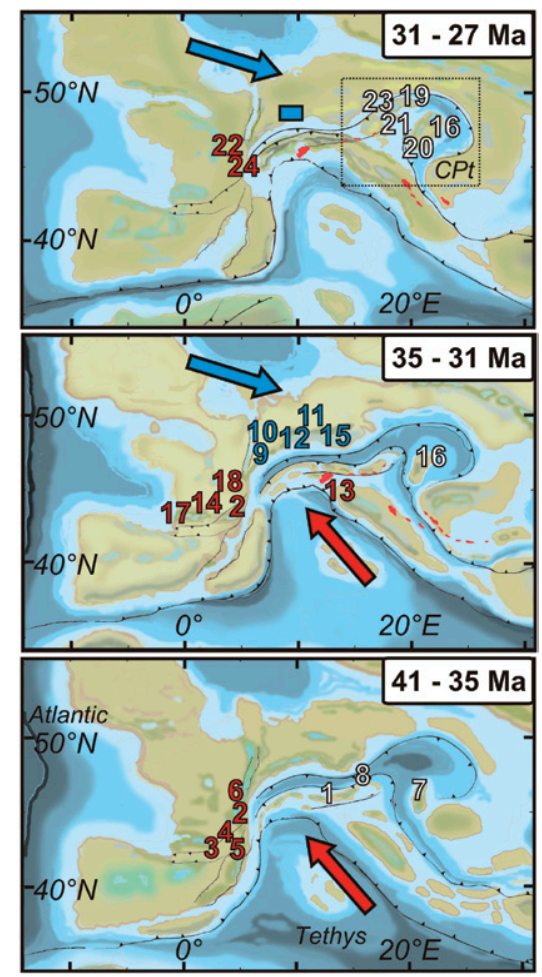

Figure 3. Paleogeographic maps of three time intervals with the paleoposition of the fossil sites (red-west-southwest; blue-north; white-east-southeast). The names of the given localities are keyed to the corresponding numbers in Figure 1. Arrows indicate major air trajectories: blue-Atlantic, red-Tethys. Blue rectangle on the top map shows the localities from where Héran et al. (2010) reported isotope data from rodents (see text). Dashed rectangle marks the Central Paratethys (CPt). Comprehensive paleogeographic maps with details on different tectonic units are provided in Figure DR2 (see footnote 1).

major changes at the time (Mosbrugger et al., 2005). Moreover, the $\delta^{13} \mathrm{C}$ values of the teeth are compatible with an already humid environment.

Considering only a minimum drop of $-2.2 \%$ in $\delta^{18} \mathrm{O}_{\mathrm{PO}_{4}}$, it can be translated to $-2.8 \%$ o $\pm 0.5 \%$ changes in $\delta^{18} \mathrm{O}_{\mathrm{MW}}$ compositions $\left(0.7 \% 0-0.9 \% 0_{\mathrm{PO}_{4}} 1 \% o_{\mathrm{MW}}\right.$; see Luz et al., 1984; Kohn and Cerling, 2002). From this, $\triangle$ MAT can be calculated, $-7.0 \pm 2.9^{\circ} \mathrm{C}$ (from $0.3 \%$ to $0.6 \%{ }_{\mathrm{MW}} /{ }^{\circ} \mathrm{C}$, representing modern and past midlatitude end members, respectively; Fricke and O'Neil, 1999). Such a temperature shift is not currently supported by any records. In addition, the global marine climate record is rather stable (Zachos et al., 2001), and the paleoflora record does not indicate any temperature change in the late Rupelian (Mosbrugger et al., 2005).

\section{Paleoaltitude}

The wide appearance of low $\delta^{18} \mathrm{O}_{\mathrm{PO}_{4}}$ values from $31 \mathrm{Ma}$ is best explained by topographyinduced fractionation of the drinking water and/ or redistribution of this water due to modifica- 
tion of drainage patterns; the latter process can be responsible for about half of the overall $4.3 \%$ o negative shift, given that in the north such low values already existed earlier (Fig. 2D). If the residual $-2.2 \% o \delta^{18} \mathrm{O}_{\mathrm{PO}_{4}}$ shift is only due to altitude, then relative elevation change can be estimated from the derived $\Delta \delta^{18} \mathrm{O}_{\mathrm{MW}}$ using global average and modern Central Alps lapse rates as two end members $(0.28 \% o / 100 \mathrm{~m}$ and $0.2 \% / 100 \mathrm{~m}$, respectively; Poage and Chamberlain, 2001; Campani et al., 2012). The calculated relative paleoelevation change is $1200 \pm 340 \mathrm{~m}$. An ancient warmer climate regime, however, would lead to even more reduced lapse rates, meaning that the obtained altitude change is a minimum estimate. This sudden uplift agrees well with other reported data, such as intensified sediment accumulation (e.g., Kuhlemann and Kempf, 2002) and comparable cooling and exhumation ages (e.g., Steck and Hunziker, 1994; Jourdan et al., 2013) which all support the enhanced emergence of the Alpine-Dinaridic orogenic belt.

\section{Eocene-Oligocene Transition Temperature Drop?}

Oxygen and carbon isotope data show that the south-southwest European climate was semiarid during the EOT. The moisture source was controlled by the warm Tethys Ocean, which buffered any global signal related to the EOT cooling event. In contrast, the sites north of the Alpine thrust (Fig. 3) had more precipitation, and the data also reveal a significant $\delta^{18} \mathrm{O}_{\mathrm{PO}_{4}}$ shift of $-1.6 \%$ exactly at the EOT (Fig. 2D; MP20 $\rightarrow$ pair-wise t-tests: MP19-20, $\mathrm{t}_{(16)}=3.87, \mathrm{p}=$ 0.001 , and MP20-21, $\left.\mathrm{t}_{(13)}=2.64, \mathrm{p}=0.02\right)$.

If this shift was only caused by $\triangle \mathrm{MAT}$, a temperature drop of $-5.1 \pm 2.1^{\circ} \mathrm{C}$ can be determined. However, at the same time more humid conditions arose (see the $\delta^{13} \mathrm{C}$ data in Fig. 2B); this complicates any certain interpretation here. For example, an increase of $10 \%$ in relative humidity $(\mathrm{RH})$ would reduce the $\triangle$ MAT to only $-1.9 \pm 0.8{ }^{\circ} \mathrm{C}\left(-0.1 \%_{\mathrm{PO}_{4}} / \%_{\mathrm{RH}}\right.$; see Kohn, 1996). Therefore, the quantitative $\triangle \mathrm{MAT}$ must be estimated with caution. Moreover, after MP20, the $\delta^{18} \mathrm{O}_{\mathrm{PO}_{4}}$ returned to previous MP19 values, indicating strengthened local conditions in this region.

\section{ACKNOWLEDGMENTS}

We thank all the scientists and institutes who provided access to fossil collections and knowledge about the studied localities: the Bavarian State Collection for Palaeontology and Geology, Munich (G. Rössner); the State Museum for Natural History, Stuttgart (E. Heizmann); the Collection of the Hungarian Geological Institute, Budapest (L. Kordos); the Hungarian Natural History Museum, Budapest (M. Gasparik); the Museum of Geology and Palaeontology, Padua (M. Fornasiero); the Fossil Collection of the University of Babes-Bolyai, Cluj (L. Silye); the Natural History Museum, Basel (L. Costeur); the Geological Museum, Lausanne (R. Marchant); and the Jura Natural Science Museum (Amalric Oriet). Constructive discussions of the data with T. Vennemann, A. Steck, and T. Tütken are much appreciated. Kocsis received funding from the Swiss National Science Foundation (grant SNF PZ00P2_126407) and Synthesys-ECR-IA-FP7 (grant HU-TAF-3454); Ozsvárt was supported by a Bolyai research grant (BO/00694/08/10), and Codrea was financially supported by the National Geographic Society (grant 8535-08). Becker's and Scherler's research was funded by the Swiss National Science Foundation (grants SNF 200121-115995/126420 and PBFRP2_145876), the Swiss Federal Roads Authority, and the Office de la Culture, République et Canton du Jura (Switzerland). We thank three anonymous reviewers for their constructive comments on an earlier version.

\section{REFERENCES CITED}

Campani, M., Mulch, A., Kempf, O., Schlunegger, F., and Mancktelow, N., 2012, Miocene paleotopography of the Central Alps: Earth and Planetary Science Letters, v. 337-338, p. 174 185, doi:10.1016/j.epsl.2012.05.017.

Erdei, B., Utescher, T., Hably, L., Tamás, J., RothNebelsick, A., and Grein, M., 2012, Early Oligocene continental climate of the Palaeogene Basin (Hungary and Slovenia) and the surrounding area: Turkish Journal of Earth Science, v. 21, p. 153-186.

Farquhar, G.D., Ehleringer, J.R., and Hubick, K.T., 1989, Carbon isotope discrimination and photosynthesis: Annual Review of Plant Physiology, v. 40, p. 503-537, doi:10.1146/annurev.pp .40 .060189 .002443 .

Fricke, C.H., and O'Neil, R.J., 1999, The correlation between ${ }^{18} \mathrm{O} /{ }^{16} \mathrm{O}$ ratios of meteoric water and surface temperature: Its use in investigating terrestrial climate change over geologic time: Earth and Planetary Science Letters, v. 170, p. 181196, doi:10.1016/S0012-821X(99)00105-3.

Gradstein, F., Ogg, J., Schmitz, M., and Ogg, G., 2012, The geologic time scale 2012: Elsevier, $1176 \mathrm{p}$.

Grimes, S.T., Hooker, J.J., Collinson, M.E., and Mattey, D.P., 2005, Temperatures of late Eocene to early Oligocene freshwaters: Geology, v. 33, p. 189-192, doi:10.1130/G21019.1.

Héran, M.-A., Lécuyer, C., and Legendre, S., 2010, Cenozoic long-term terrestrial climatic evolution in Germany tracked by $\delta^{18} \mathrm{O}$ of rodent tooth phosphate: Palaeogeography, Palaeoclimatology, Palaeoecology, v. 285, p. 331342, doi:10.1016/j.palaeo.2009.11.030.

Hooker, J.J., Collinson, M.E., and Sille, N.P., 2004, Eocene-Oligocene mammalian faunal turnover in the Hampshire Basin, UK: Calibration to the global time scale and the major cooling event: Geological Society of London Journal, v. 161, p. 161-172, doi:10.1144/0016-764903-091.

Hren, M.T., Sheldon, N.D., Grimes, S.T., Collinson, M.E., Hooker, J.J., Bugler, M., and Lohmann, K.C., 2013, Terrestrial cooling in northern Europe during the Eocene-Oligocene transition: National Academy of Sciences Proceedings, v. 110 , p. $7562-7567$, doi:10.1073 /pnas. 1210930110.

Jourdan, S., Bernet, M., Tricart, P., Hardwick, E., Paquette, J.-L., Guillot, S., Dumont, T., and Schwartz, S., 2013, Short-lived, fast erosional exhumation of the internal western Alps during the late early Oligocene: Constraints from geothermochronology of pro- and retro-side foreland basin sediments: Lithosphere, v. 5 , p. 211-225, doi:10.1130/L243.1.

Katz, M.E., Miller, K.G., Wright, J.D., Wade, B.S., Browning, J.V., Cramer, B.S., and Rosenthal, Y., 2008, Stepwise transition from the Eocene greenhouse to the Oligocene icehouse: Nature Geoscience, v. 1, p. 329-334, doi:10.1038/ngeo179.

Kohn, M.J., 1996, Predicting animal $\delta^{18} \mathrm{O}$ : Accounting for diet and physiological adaptation: Geo- chimica et Cosmochimica Acta, v. 60, p. 48114829, doi:10.1016/S0016-7037(96)00240-2.

Kohn, M.J., 2010, Carbon isotope compositions of terrestrial C3 plants as indicators of (paleo) ecology and (paleo)climate: National Academy of Sciences Proceedings, v. 107, p. 1969119695, doi:10.1073/pnas.1004933107.

Kohn, M.J., and Cerling, T.E., 2002, Stable isotopes of biological apatite, in Kohn, M.L., et al., eds., Phosphates: Geochemical, geobiological and materials importance: Mineralogical Society of America Reviews in Mineralogy Volume 48, p. $455-488$.

Kuhlemann, J., and Kempf, O., 2002, Post-Eocene evolution of the North Alpine foreland basin and its response to Alpine tectonics: Sedimentary Geology, v. 152 , p. 45-78, doi:10.1016 /S0037-0738(01)00285-8.

Luz, B., Kolodny, Y., and Horowitz, M., 1984, Fractionation of oxygen isotopes between mammalian bone-phosphate and environmental drinking water: Geochimica et Cosmochimica Acta, v. 48, p. 1689-1693, doi:10.1016/0016-7037 (84)90338-7.

Mosbrugger, V., Utescher, T., and Dilcher, D., 2005, Cenozoic continental climatic evolution of Central Europe: National Academy of Sciences Proceedings, v. 102, p. 14964-14969, doi:10.1073 /pnas.0505267102.

Poage, M.A., and Chamberlain, C.P., 2001, Empirical relationships between elevation and the stable isotope composition of precipitation and surface waters: Considerations for studies of paleoelevation change: American Journal of Science, v. 301, p. 1-15, doi:10.2475/ajs.301.1.1.

Schmid, S.M., Bernoulli, D., Fügenschuh, B., Matenco, L., Scheffer, S., Schuster, R., Tischler, M., and Ustaszewski, K., 2008, The AlpineCarpathian-Dinaridic orogenic system: Correlation and evolution of tectonic units: Swiss Journal of Geosciences, v. 101, p. 139-183, doi:10.1007/s00015-008-1247-3.

Steck, A., and Hunziker, J., 1994, The Tertiary structural and thermal evolution of the Central AlpsCompressional and extensional structures in an orogenic belt: Tectonophysics, v. 238, p. 229 254, doi:10.1016/0040-1951(94)90058-2.

Stehlin, H.G., 1909, Remarques sur les faunules des mammifères des couches éocènes et oligocène du Bassin de Paris: Bulletin de la Société Géologique de France, v. 9, p. 488-520.

Tipple, B.J., Meyers, S.R., and Pagani, M., 2010, Carbon isotope ratio of Cenozoic $\mathrm{CO}_{2}$ : A comparative evaluation of available geochemical proxies: Paleoceanography, v. 25, PA3202, doi: 10.1029/2009PA001851.

Zachos, J.C., Pagani, M., Sloan, L., Thomas, E., and Billups, K., 2001, Trends, rhythms, and aberrations in global climate 65 Ma to Present: Science, v. 292, p. 686-693, doi:10.1126 /science.1059412.

Zanazzi, A., Kohn, M.J., MacFadden, B.J., and Terry, D.O., Jr., 2007, Large temperature drop across the Eocene-Oligocene transition in central North America: Nature, v. 445, p. 639-642, doi: 10.1038/nature05551.

Zazzo, A., Lécuyer, C., and Mariotti, A., 2004, Experimentally-controlled carbon and oxygen isotope exchange between bioapatites and water under inorganic and microbially-mediated conditions: Geochimica et Cosmochimica Acta, v. 68, p. 1-12, doi:10.1016/S0016-7037(03)00278-3.

Manuscript received 13 March 2014

Revised manuscript received 5 June 2014

Manuscript accepted 9 June 2014

Printed in USA 